\title{
Topic:
}

\section{Management Learning in Business Networks: the process and the effects}

\author{
Abstract \\ This article studies the process of firm learning in business networks and its impact on new \\ product development (NPD). It argues that prior work offers little insight into how learning \\ actually takes place in network collaboration, and so poses the open question of whether \\ learning through business networks does accelerate NPD. The paper begins by clarifying \\ important learning concepts. It then documents how these concepts evolve across \\ organizational boundaries and projects and also over time. It also shows how companies \\ apply the skills of dialogue, articulation and experience for knowledge transfer (KT) and how \\ they engage in articulation and pollination for knowledge cross-transformation (KCT). \\ However, despite being able to document these processes, we are unable to unequivocally \\ link KT with NPD efficiency and conclude that the latter is enhanced by KCT. This article \\ contributes to a theoretical inter-organisational learning model in business networks and \\ suggests improved ways for management learning.
}

\section{Keywords}

Firm learning, business networks, pollination, knowledge transfer, knowledge crosstransformation 


\section{Introduction}

There is widespread agreement that management learning is a complex social process (Antonacopoulou and Chiva, 2007) and that this complexity increases when it takes place, not simply within a single firm, but when the firm learns through networking with other enterprises. Prior research on management learning in network contexts (Miettinen, Lehenkari and Tunnainen, 2008; Kogut, 2000; Walter, Lechner and Kellermanns, 2007; Enberg, Lindkvist and Tell, 2006; Owen-Smith and Powell, 2004) has produced diverse, even contradictory results, often raising more questions than it answers. Most notably, whilst it is clear that the impact of network collaboration on the success of projects varies considerably, the reasons for this are somewhat opaque (Knudsen and Mortensen 2011; van de Vrande, de Jong,Vanhaverbeke and Rochemont, 2009).

This paper argues that this opacity is, at least partly, attributable to the outcomes from learning being either too diverse or imperfectly specified. The paper addresses this by focussing upon a single outcome - the speed of new product development (NPD). Prior work (Van de Vrande et al., 2009) has shown that firm learning in an open environment helps to shorten the project time taken in completing complex tasks such as new product development. However, Miettinen et al. (2008); Kogut (2000); Mansfield (1988); and Clark, Chew and Fujimoto (1987) all point to the links between the effects of NPD speed and firm learning in network collaboration being less consistent. We suggest this ambiguity may reflect our imperfect understanding of the underlying processes of management learning within networks of enterprises. To address these issues we pose two questions. First, how is firm learning processed in network collaboration? Second, what skills do companies apply in this process? To address the questions we used a mixed-methods research approach to first develop, and then to test, the elements of a conceptual network learning model. 
The paper contributes to knowledge along four dimensions. First, it uses a robust research approach by providing a theoretical model, through a multiple-case study, that links closely with existing literature seeking to explain a complex multidimensional networklearning process; it then tests that model using large-scale survey research. Second, it responds to the many calls for an improved understanding of the concept of 'co-evolution' that underlies much of the study of management learning in business network collaboration. Third, by investigating NPD speed, the paper provides insights into the causes of the inconsistent results on the effect of network learning that have been found in prior work. Finally, it offers practical guidance for mangers seeking to learn in a context of network collaboration.

\section{Theoretical background}

\section{Firm learning within business networks}

Within the single firm model, scholars (e.g. DiBella, Nevis and Could, 1996; Daft and Weick, 1984) suggest that evidence of firm learning is reflected in the ability of the enterprise to cope successfully with business environmental change. Experiential improvement and interaction with, and response to, the environment have been emphasised as important contexts for firm learning (Antonacopoulou, 2006; Argyris and Schön, 1978). Asking the right questions at the right time, absorbing the answers, sharing understanding of their implications and acting decisively provides a framework for addressing the process of learning (Cyert and March, 1963). This firm-learning process has become well-established and developed into the mechanism of knowledge acquisition or recognition (asking right questions), transmission or assimilation (sharing understanding), and application (acting based on the understanding) (Day, 2002; Sinkula, 1994; Huber 1991; Daft and Weick, 1984). 
However understanding the process of firm learning becomes more complex in a multi-firm context. The organisational learning literature suggests that inter-firm learning can be viewed as the collective acquisition of knowledge and skills (Knoppen, Sáenz and Johnston, 2011; Ingram, 2002; Halme, 2001). It differs from learning at the individual firm level because it also incorporates the synergies derived from the interaction between firms (Larsson, Bengtsson, Henriksson and Sparks, 1998). Inter-firm learning can therefore be viewed as the joint outcome of a firm's intent and its ability to turn learning objects (e.g. knowledge) into a form that is transparent and receptive to its learning partner (Larsson et al., 1998; Inkpen, 1996; Hamel, 1991). This has led researchers to develop, and then study, the concepts of ‘dialogue’ and ‘articulation’ (Larsson et al., 1998; Nonaka, 1994; Huber, 1991). They show ‘dialogue' helps to transmit a firm’s intent of learning and ‘articulation' (i.e. turning tacit knowledge explicit) helps to enhance a firm’s ability to learn (Zollo and Winter, 2002; Hedlund, 1994).

Firm learning in network settings is, however, analytically different from inter-firm learning (Håkansson and Johanson, 2001) for several reasons. First, network alliances allow firms to combine knowledge, skills and physical assets on a multidimensional and multifaceted scale. Second, collaborative linkages provide access to knowledge spillovers, serving as information conduits through which information flows and, in turn, leads to technical breakthroughs and new insights (Owen-Smith and Powell, 2004; Walter et al., 2007). Business networks (e.g. customers, suppliers and competitors) therefore promote learning and also provide the resources for addressing uncertainties and for solving problems in a volatile business environment (Gulati, 1999; Owen-Smith and Powell, 2004).

Several prior studies have examined firm learning within business networks. The review by Miettinen et al. (2008) is very relevant for the current research. They show the organisational learning literature conceptualises the processes of organisational and 
managerial routines in the act of knowledge transfer (Teece and Pisano, 1994; Inkpen, 2000), with a distinction being drawn between the acts of acquisition, assimilation and application (Rindfleisch and Moorman, 2001). They also claim that a 'path' composed of successive innovation processes is a hybrid phenomenon, stressing that in every new collaborative innovation the prior resource, knowledge and competencies of the firm are complemented, so making ‘co-evolution’ possible (Antonacopoulou and Chiva, 2007). Business networks also offer the benefit of both specialisation and variety generation (Kogut, 2000). Firm learning within business networks is central to interdependence as it is the driving force connecting these diverse and heterogeneous forms of knowledge. Put differently, network learning provides opportunities for mutual learning that stimulates the creation of new knowledge (Walter et al., 2007; Enberg et al., 2006).

From this research, several important concepts have emerged. For example, Miettinen et al., who study biotechnology firms, have found that a firm's core competence is enhanced by accumulating new knowledge through network collaboration. These effects have been characterised in the literature as 'combinative capability' developed earlier by Kogut and Zander (1992) who argue that the source of firms' inimitability comes from the totality of the organizations as a collaborative 'social community'. The concept of 'collective invention' raised by Allen (1983) stresses the importance of these collective benefits with, for example, van de Vrande et al. (2009) and Hemesberger and Reinhardt (2006) claiming it is a key mechanism for generating new knowledge. Powell, Koput and Smith-Doerr (1996) emphasized that the need to combine complementary sources of knowledge has played a central role in the growth of firms' network collaboration. This is supported by Rindfleisch and Moorman (2001) who show that collaborating with networked partners allows companies to combine knowledge and also provides access to knowledge spillovers for technical breakthroughs. Walter et al. (2007) make a similar point by emphasising the 'collective 
benefits’ created by knowledge being transferred within the network of alliance partners. Networks also offer the benefit of both specialization and variety generation. The collaboration between networked firms shapes the combinative and collective effects. These effects lead to the learning that takes place as a condition for firms' 'co-evolution' (Kogut, 2000; Antonacopoulou and Chiva, 2007; Walter et al., 2007; Miettinen et al., 2008).

\section{The effects of firm learning through business networks}

We now review the role and nature of firm learning in business networks, emphasising the inconsistent, and sometimes contradictory, findings from prior work. To maintain or enhance their competitive advantage, firms frequently acquire external knowledge through business networks (Rosenberg and Steinmueller, 1988; Brown and Duguid, 2002). As an example, Kogut (2000) studied the supplier system of the Toyota Product System and found that outside suppliers clearly enhanced new product development. Clark, Chew and Fujimoto (1987) and Mansfield (1988) also found that a policy of outsourcing to suppliers increased speed to market, highlighting the value of exploiting the knowledge of other firms. Where matters are less clear is whether learning within business networks speeds outcomes such as New Product development (NPD).

Evidence of a positive link is provided by Lynch and O’Toole (2006). They found that companies which shared the knowledge they obtained from external alliances had faster rates of new product speed to market. Singer and Helferich (2008) broadly confirm this result showing that knowledge exchange through business networking shortens product innovation and development time. Further support comes from Johnson, Piccolotto and Filippini (2009), who find that knowledge transfer through networking enhances product development speed. Finally, van de Vrande et al. (2009) examine small- and medium-sized enterprises and find 
that learning in product innovation networks allows companies to overcome specific knowledge gaps in a cost-effective manner.

The single most crucial task in successful product innovation and development activities is widely recognised to be the ability to solve problems (Von Hippel, 1990; Enberg et al., 2006). For this reason, the finding by Duysters and de Man (2003) that strategic alliances with other organizations help companies to acquire knowledge and to solve problems more swiftly, is important. Atuahene-Gima and Wei (2011) confirm this, but emphasise that such knowledge has to be used to solve problems speedily. Superior knowledge, per se, does not therefore automatically speed product development. Instead, companies often need 'other skills' for this to take place, although the nature of these 'other skills’ was not specified.

Other empirical evidence seeking a link between learning through network collaboration and product development speed, is less clear-cut. For example, Appleyard, Brown and Sattler (2006) in their study of the semiconductor industry in Japan, South Korea and the United States found no evidence of an association between knowledge acquisition through learning from external sources and problem-solving speed in product development. Even more extreme are the findings of Knudsen and Mortensen (2011) who found that external network learning slowed product development and lengthened time to market. However the reasons for this were unclear.

Other empirical work has also questioned the presence of a simple link between learning and knowledge on the one hand and measures of firm performance on the other. For example, Akgün, Byrne, Keskin, Lynn and Imamoglu (2005) found that the role of the knowledge network had a bigger impact on speed-to-market in complex, than in simpler, product development projects. Kessler, Bierly and Gopalakrishnan (2000) found that the process of external learning slowed later stage product development. They argue that this 
may be caused by the inability of network actors to convert tacit into explicit knowledge. Finally, Frankish, Roberts, Coad, Spears and Storey (2013) examine the evidence for learning amongst owners of wholly new enterprises. They make the theoretical case that learning is, by definition, impossible under "lottery conditions" - the lottery winners win by luck not by learning how to play the lottery; and that these conditions apply for new enterprises. They then define three measures of learning and find no evidence of learning for any of these measures.

The above review suggests that the underpinning theory of learning within business networks is rather sketchy and so it is hardly surprising that the empirical findings are, at best, ambiguous. As discussed in the previous section, the learning of competence that enables products to be competitive in the market place is essential (Kogut, 2000; Miettinen et al., 2008). However, attempts (Antonacopoulou and Chiva, 2007; van de Vrande et al., 2009) to define management capabilities in a network setting, such as co-evolution and collective invention, remain problematic. As a minimum we need to better understand the underlying principles of this form of learning by gaining empirical insights into the processes of learning through knowledge exchange and knowledge building and to use these to 're-theorise' how learning emerges from external collaboration (Schneider, 2007). This may enable us to better understand when and why negative associations between business network learning and product development speed are possible. It also raises questions about how companies engage with their network partners, perhaps pointing to the absence of either 'other skills' (Atuahene-Gima and Wei, 2011) or of individual 'converters' that are able to enhance the process of learning. Overall, the literature points us to the importance of understanding the process of learning in business networks and the skills companies apply in this process. Ultimately this better understanding of the knowledge process should enable us to reach a 
judgement on the effect of this learning from the perspective of product development's efficiency.

\section{The study and research method}

Our task is to examine the link between learning in networks and NPD. We begin by clarifying the terms to be used. Process is defined as a series of actions taken to achieve a particular end (Oxford, 2009). In this research, we study process in the context of intentional learning (Huber, 1991) in business networks. We view learning in business networks as an intentional process (or a series of actions) directed at improving NPD effectiveness (Powell et al., 1996). Business networks are defined as a firms’ set of embedded business relationships (Granovetter, 1985) with other organizations. Relationships or linkages are defined as 'interorganisational' interaction processes and bonds with economic targets, directed to a sequence of exchange (Håkansson and Ford, 2002). Business networks therefore involve multi-faceted inter-organizational relationships that are more complex than interactions taking place in a dyadic inter-organizational relationship. The scope of business network alliances used in this study is based on both the paradigm of vertical (e.g. supplier) and horizontal (e.g. competitor) embedded relations (Stuart, 1998) and the theory of direct (e.g. customer) and indirect (e.g. customer's customer) ties (Ahuja, 2000). Successful product development is defined as ‘a project that incorporates a new product that has been brought from idea to commercial successes’ (Cooper 1993).

Our study adopts a 'pragmatist' philosophical view (Morgan, 2007; Creswell, 2009) and uses sequential exploratory mix-methods research (Creswell, 2003) to propose and examine theory. Phase One focuses on theory building (Eisenhardt, 1989) through multiple case studies in exploring the business network learning process and how firms engage with their allies within this process. However, network studies involve complex multifaceted 
issues that pose challenges for researchers (Håkansson and Johnson, 2001). To address these challenges we used a 'hub and spoke' approach. A hub company was one with a successful product development project. Through referral, samples were snow-balled to identify 'spoke' companies. A spoke company was one that networked and collaborated with the hub company in the successful project. This snow-balling technique provided data on the embedded direct (e.g. a customer) and indirect (e.g. the customer's customer) networked relationships. To ensure reliability, data from the semi-structured interviews with key informants was transcribed, with the informants then given the opportunity to review the transcript (Yin, 2003). Only minor corrections were made. NVivo 7 was used to manage the data.

Phase Two examined the conceptual model that emerged from Phase One. Data were collected from the Scottish-Enterprise directory (2008 - 2009). SNAP 9 Professional was used to create an on-line questionnaire composed of closed-end questions. Multi-item scales measured constructs derived from the existing literature. The remaining constructs were derived either from results of phase one interviews or from the literature review. Samples were screened by emails and phone calls for companies with successful new product development projects in the past three years. To test the proposed conceptual model, we used Structural Equation Modelling (SEM/AMOS 18.0) that allowed us to estimate multiple and interrelated dependence relationships. Before conducting SEM testing, we used Confirmatory Factor Analyses to assess validity and dimensionality of the measure.

\section{Phase One: The conceptual model}

To develop a conceptual model, Phase One began with three hub companies in E-Business, Tourism, and Energy. They were chosen because they already had a successful product 
development with networked partners. Hub E-Business was an independent supplier of internet products and services for business customers. Hub Tourism provided customers such as hotels with on-line services. Hub Energy was a mechanical engineering company. The first step was to identify the 'spoke' companies which are networked, either as direct ties (e.g. its customer) or as in-direct ties (e.g. its customer’s customer) with the hub (Ahuja 2000). Appendix 2 summarises the role of the sampled companies.

Within-case data were first, word by word transcribed, as detailed case studies. To analyse the data, we used the processes of 'seeing plausibility' to code data; 'clustering', and ‘comparison and contrasting' to category data (Miles and Huberman, 1994). Categorised themes were measured by using the technique of 'counting' (Miles and Huberman, 1994) to judge issues as 'important' or 'significant' or 'recurrent'. We measured the number of interviewees whose statements affirmed/implied the corresponding themes (or skills). Key themes were decided by a threshold of $50 \%$ or over of counts. In searching for cross-case patterns, the pattern-match and 'replication logic' approaches were used (Eisenhardt, 1989). To search for patterns, the process of 'constant comparison' and 'counting' technique' (Miles and Huberman, 1994) was used. A conceptual model was shaped and proposed through the reiterated steps of enfolding literature (Eisenhardt 1989; Yin 2003). Appendix 1a and 1b provide a description and antecedents of the emerged patterns, and summarises the cross-case patterns by comparing findings in three cases. Further information is available from the corresponding author.

Following Gioia, Corley and Hamilton (2012), we built a data structure consists of a set of $1^{\text {st }}$-order concepts, $2^{\text {nd }}$-order themes and aggregate dimensions. Figure 1 summarises this set of data structure on which we built our modle of network learning process. The emergent themes were compared with the theories/concepts from the existing literature (Eisenhardt, 1989). Table 1 provides a summary of these emergent themes, the number of 
interviewees whose statements affirm the themes and the supported literature. Next section discusses the details.

(Insert Figure 1 here)

(Insert Table 1 here)

\section{Network learning process}

The cases suggest that, in co-projects, the transfer of knowledge is the initial step in processing learning in business networks, so confirming the earlier work of Galbraith (1973), Inkpen (2000) and Walter et al. (2007). However, our data also reveals the transfer of knowledge, of itself, is not sufficient to depict how learning is processed in product development networks. One informant stressed:

“...Relying on passing know-how is not enough! We need new ideas and we need the cooperation with all our partners... without integrating their ideas, it is just impossible...” (e-Business Hub).

In fact, the process of knowledge transfer has been argued by Nonaka and Takeuchi (1995) to be particularly problematic when dealing with novelty. Reflecting this, a Tourism respondent said:

"...they (the hub company) went away with the feedback we gave them, incorporating some elements from their customer into it, to get it to work, and then asked us to produce the product. This is good for both companies (the hub and its supplier). Because not only did it create a solution that was the best for them, but also it helped us to get new ideas. And we then used this advanced technology to other companies...I know they (hub) are doing the same thing and some of our suppliers are too... This is truly a win-win-win game, they (the hub company) win, our customers win, and of course we win as well!!”(Tourism, supplier-1) 
With some notable exceptions, the issue of knowledge transformation (KT), captured in the above quote, has received limited attention amongst researchers. The exception is Halme (2001) who found network learning may produce exchange-type transactional outcomes so that completely new knowledge can be created. Miettinen et al. (2008) also recognize this complementarity and highlight the importance of co-evolution.

Prior work suggests that a company’s understanding of a new product or process improves not only by the knowledge of being 'transferred' by the partner company, but also by accommodating it within its own work, so enriching its knowledge stock (Liu and Hart, 2011). There is clear evidence that knowledge exchange within alliance partners is positively associated with innovative and higher-level capability (Walter et al., 2007). It is this process of building and applying new knowledge through the ability to 'transform' that creates broader shared minds (Miettinen et al., 2008). ‘Knowledge transformation’ (KT) therefore serves to enhance our understanding of the process of knowledge-building in a dyadic interorganisational relationship.

Nevertheless, knowledge transformation seems insufficient to explain the learning process in a multifaceted network relationship which we observe in our Phase One cases. This is because companies derive knowledge from different network partners, so new knowledge then emerges from combining and reconfiguring that knowledge and then sharing it back with the partners. Kogut (2000) also observed this effect, referring to it as 'coevolving' (2000: 422). Through this process, companies first transfer knowledge and then advance their existing knowledge and create new ideas through a 'cross-effect' (Pyka, 2002). For example, in the tourism case, new knowledge was created through the collaboration between the hub and its supplier. With that new knowledge, both the hub and its supplier generated more new ideas/knowledge when they worked with other network partners. We refer to this as the 'knowledge cross-transformation' (KCT). We therefore propose: 
H1: Companies learn in their business networks by a process of knowledge transfer and knowledge cross-transformation for product development. In this process, better knowledge transfer leads to better knowledge cross-transformation.

To explore how the learning process actually worked, informants were probed on the skills required for this to be effective. Unsurprisingly, they emphasised listening and talking to knowledgeable people in their allied networks so as to transmit the intent of learning (Larsson et al., 1998) and to identify the required knowledge (Inkpen, 1996). This engagement echoes Isaacs’ (1993) concept of ‘dialogue’ which Hazen (1994) defines as a method when people speak and listen to each another in mutuality, reciprocity and co-inquiry. Isaccs (1993) views dialogue as a sustained collective inquiry in the learning processes that comprise collective thinking. In this sense, the discipline of dialogue is central for a company engaged in transfer knowledge because it holds promise as a means for promoting collective thinking and communication (Cyert and March, 1963; Beamish and Berdrow, 2003). This leads us to propose:

H2a: Dialogue improves knowledge transfer in product development network collaboration.

In the context of product development, knowledge is often 'tacit' in nature (uncodified and difficult to share) (Grant 1996). This problem was captured by an E-Business respondent who said:

'Clients found it difficult to understand us, and we found difficult to understand them....it was a big mess...' (E-Business Hub) 
Successful companies addressed this problem by making tacit knowledge more explicit through discussions with experienced personnel, and even by trial and error. Nonaka (1994) and Bresman et al. (1999) use the term 'articulation' to describe the skill of turning tacit knowledge into explicit knowledge. Polanyi (1966), for example, says 'we know more than we can tell' and recognizes an inarticulate component of knowledge, which he terms the tacit dimension. Hedlund (1994) observed that many firms are 'articulation machines', built around codified practices which convert tacit into explicit knowledge. Cohendet and Llerena (2007) emphasised that shared codes and a common language play key roles in knowledge exchange and product development projects. Kale and Singh (2007) also noticed that, in network alliances, knowledge and know-how is often 'tacit'. They claim that companies often make efforts in 'articulation' to turn tacit, into explicit, knowledge. This leads us to propose:

H2b: Articulation enhances knowledge transfer in product development network collaboration.

Phase One also pointed to another important theme - prior experience. It was clear that to facilitate knowledge transfer in network learning companies often used prior knowledge and expertise with their network partners' technology and process know-how. One respondent said:

“...We understand 'learning' is a tough job, you cannot just give them (a network partner) a book and say 'go home and study'. It just doesn't work that way. We decide what (i.e. knowledge) we can pass to them based on their existing experience...Something like you guys in the university, asking for 'prerequisite course' before students are allowed to take next level's course...' (e-Business, customer-1) 
This is consistent with the findings of Liu and Hart (2011) and of Simonin (1999). Powell (1998) also claims that prior expertise with network partners' know-how improves knowledge acquisition. Pyka (2002) goes further and argues that, without a common knowledge base and shared experience with allied partners, even simple knowledge transfer is not possible. We therefore propose:

H2c: Prior experience positively impacts on knowledge transfer in product development network collaboration.

To elaborate how knowledge cross-transformation takes place, the 'fusion effect' by which companies consolidate and integrate knowledge from different sources is described by an E-Business respondent:

“...One of the key elements to our successful innovation lies in our company culture. This culture is based on a rich 'fusion' approach that makes our company unique. The fusion comes from a rich combination of experts! The culture is not only an internal matter, but it is taking place in our entire supply chain...” (E-Business hub)

Previous collaborative projects also provide a stock of knowledge, so that current projects benefited from its 'infusion’. An Energy respondent recalled:

“...This goes back to the knowledge we learnt from our previous project where we worked with many great companies. I have been in this industry for more than twelve years; Gary, our marketing Director, eight years; and Paul, production Director, ten years. When I presented my team with the problem I learnt from an international conference, we were all very excited. We saw a potential opportunity for our company. Yes, our previous knowledge inspired us with the new idea for this project (the studied successful product development projects). Because the entire team has been working with so many companies, we've already had an idea where we could use it and which problem it could solve...” (Energy, customer-2) 
The Phase One findings suggest companies apply a skill to be 'fertilized' with diversified knowledge going beyond the boundaries of organisations, projects and even timeframes. Only a few researchers have examined this issue but, amongst those that have, Bechky (2003) claims that 'when a member of one community came to understand how new knowledge from another community fitted within the context of his own work, it enriched what he knew’ (p.321). Pyka (2002) also highlights a fusion of different capabilities that transform a stock of knowledge into novel ideas which explore new opportunities. We use the term 'pollination' to describe this nuanced skill. It captures the concept of being fertilized by the pollen of knowledge obtained beyond organizational boundaries (i.e. different network partners), through different projects and across different time-frames. Figure 2 shows this effect can be horizontal (in present co-projects) and/or vertical (in different co-projects at different time-frame).

(Insert Figure 2 here)

Tacit knowledge can also influence the process of knowledge cross-transformation, but turning tacit into explicit knowledge requires the skill of 'articulation'. An example of this is provided by the Energy respondent:

“...we finally got all the parties who are interested in 'size making' together to talk about what to do next...BUT, big problem came. We didn't 'read' each other... at the end, everybody was just wasting time....” (Energy, supplier-1)

When asked how they solved the problem, the respondent continued:

"We often have conference calls with all involved parties (i.e. supplier, customer and customer's customer). We studied complete set of plans and had many discussions with all involved parties....the purpose is to align everyone to the overall project...to 
make sure we all understand each other and we encourage our suppliers to do the same thing." (Energy, supplier-1)

Given our theorising of 'knowledge cross-transformation' we need to understand how it is linked by the skills of pollination and articulation. We therefore propose:

H3a: Pollination positively impacts on knowledge cross-transformation in product development network collaboration.

H3b: Articulation positively impacts on knowledge cross-transformation in product development network collaboration.

\section{Network learning process and its effects}

Although both Johnson et al. (2009) and van de Vrande et al. (2009) find knowledge transfer enhances product development speed, this is not supported by our Phase One evidence. Instead we find product development speed is more likely to be enhanced by knowledge cross-transformation as articulated by the respondent from Tourism:

“...Oh, yes. Without working with our network partners, our idea would just not be developed into a product so quickly, nor it would not be a product at all...It is definitely not from only one single partner, but it is really the cooperation from all involved parties... our suppliers, customers, customers' customers....” (Tourism, Hub)

The E-Business respondent made a similar point:

“...it is the fusion culture by working together and learning together that helps us to our product to launch quicker... Today we may be a student to learn from our working partner; tomorrow we may turn into a teacher to teach others what we have learnt....This is the benefit we got from our network partners. Just passing on their 
knowledge will not help our product get into the market faster. We need that 'fusion' effect for new ideas”. (E-Business Hub)

This emphasises that, in network learning, the mere transfer of knowledge is not sufficient to improve product development speed. Instead what is required is knowledge cross-transformation. We thus propose:

H4a: Knowledge transfer does not impact on product development speed.

H4b: Knowledge cross-transformation positively impacts on product development speed.

The results of our qualitative research suggest a learning process which is set out in Figure 3. It identifies Knowledge Transfer (KT) and Knowledge Cross-transformation (KCT) and implies KT leads KCT. Dialogue and Experience only get reflected in Knowledge Transfer (KT). Articulation affects both KT and Knowledge Cross-Transformation (KCT). Pollination only affects KCT, and not KT. Finally, KT has a direct effect on KCT and an indirect effect on Product Development Speed (PDS). It implies that better KT leads to better KCT (H1). Specifically, the skills of dialogue, articulation and experience positively enhance KT (H2a, H2b and H2c); the skills of pollination and articulation enhance KCT (H3a and H3b); KCT, rather than KT accelerates product development (H4b and H4a).

(Insert Figure 3 here)

\section{Phase Two: Testing the conceptual model}

To test the model, primary data were collected using a web survey administered to companies that work with network partner(s) and have had successful product development projects in 
the past three years. This is defined as a project that has been brought from idea to commercial success (Griffin and Page 1996). As noted earlier, the sampling frame used was the Scottish-Enterprise Directory. Eleven sectors were included: food and beverages, finance and insurance, petroleum and fuel, chemicals and pharmaceuticals, rubber and plastic, hotel/tourism/leisure, machinery and equipment, hi-tech and e-business, telecommunications, building and construction, consultancy/research/training. 3,650 companies were randomly selected.

After eliminating those that were incorrect or inappropriate, 3,216 were emailed a letter. It explained the purpose was to better understand company practice in working with network partner(s). To be included the company had to have had experience of a successful product development project(s) during the previous three years. The term "successful product development project” was defined. Three weeks after the initial contact, nonrespondents were telephoned, reminded of the questionnaire, and encouraged to complete and return it. A second follow-up was made by email. This yielded a total of 211 usable responses or a response rate of $6.6 \%$. To detect whether there is any issue caused by low response rate, we have conducted a non-response bias test. Using the Extrapolation method (Lambert and Harrington, 1990; Armstrong and Overton, 1977) to test non-response bias, no clear response bias detected. Further information is available from the corresponding author.

Respondents were asked about company practice in working with their 'important' network partner(s) in a successful new product development project (s) over the previous three years. All items were assessed using a seven-point Likert scale with anchors of: never (1) and always (7). To test the hypotheses, four constructs were derived from previous measures; and three constructs were developed from our Phase One findings. Where these had been used in previous work we used the same constructs. For 'speed' we used Akgün and Lynn’s (2002) work on product development team improvisation and speed-to-market 
(Cronbach alpha $=0.88)$. For 'knowledge transfer', we used Moorman (1995) items for knowledge acquisition and transmission processes $(\alpha=0.70)$. For 'articulation' $(\alpha=0.75)$ we used Bresman, Birkinshaw and Nobel (1999) work. For 'experience’ $(\alpha=0.93)$ we used Simonin (1999). The above constructs showed acceptable reliability estimates (0.70 - 0.93). However some constructs - ‘cross-transformation’ and the two antecedent constructs ‘dialogue’ and ‘pollination’ were not available from prior work, so we used our findings from Phase One of our study. Appendix 1(a) and Appendex 1(b) provide more complete documentation.

The validity and unidimensionality of the measure was examined by Confirmatory Factor Analyses (CFA). The model fit statistics were satisfactory: GFI=.94; CFI=.97; $T L I=.96 ; R M S E A=.05$ and $\chi^{2}(69)=107.395, p<.01$ (Baumgartner and Homburg, 1996). The degrees of freedom ratios were acceptable $\chi^{2} / d f=1.52$. Descriptive statistics and correlation coefficients were also shown in Appendix 1. Composite Reliabilities (CR) ranged from .66 to .89 , and average variance extracted $(A V E)$ ranged from .50 to .81 . Discriminant validity was assessed by comparing the shared variance (squared correlation) between each pair of constructs against the average of the AVEs for these two constructs. Within each of the ten pairs of constructs, the shared variance observed was lower than the average of their AVEs, indicating discriminant validity (Fornell and Larker, 1981). We also tested for multicollinearity between knowledge transfer and knowledge cross-transformation, between dialogue and articulation and between articulation and pollination using a bootstrapping mediation test in Amos 18. Mediation effects were evidenced (Zhao, Lynch and Chen, 2010), implying multicollinearity was not an issue.

Structural Equation Modelling (SEM/AMOS 18.0) was used to test the hypotheses. The hypothesized model fits the data well as indicated by fit indices of $\chi^{2}(76)=133.62$, $p<0.001, G F I=.92, C F I=.96, T L I=.94, R M S E A=.06$. The degrees of freedom ratios were 
acceptable $\chi^{2} / d f=1.68$. The SEM testing results that appeared in Table 2 were illustrated in Figure 4, and are now reviewed. First, the correlation between knowledge transfer and crosstransformation (H1) was positive and significant (standardized regression estimate $\beta=0.35$ at $p<0.01$ level). Hypothesis 1 was therefore supported. Furthermore, the correlation between dialogue and knowledge transfer (H2a)was significant $(\beta=0.27, p<0.05$ level); between articulation and knowledge transfer (H2b) was significant $(\beta=0.44, p<0.01$ level); and between experience and knowledge transfer $(\mathrm{H} 2 \mathrm{c})$ was also significant $(\beta=0.23, p<0.01)$. Three hypotheses (H2a, H2b and H2c) were supported. The correlation between pollination and knowledge cross-transformation (H3a) $(\beta=0.25$, $p<0.05$ level) was significant, as was that between articulation and knowledge cross-transformation (H3b) $(\beta=0.32, p<0.05)$. Hypothesis 3a and Hypothesis 3b were supported. Finally, the correlation between knowledge transfer and product development speed (H4a) was insignificant, whereas that between knowledge cross-transformation and product development speed (H4b) was significant $(\beta=0.35$ at $p<0.05)$. Hypothesis $4 \mathrm{a}$ and Hypothesis $4 \mathrm{~b}$ were therefore supported. One set of mediating effects was also detected: Knowledge Cross-Transformation (KCT) as mediator, Knowledge Transfer (KT) as antecedent, and Product Development Speed (PDS) as dependent variables. Mediating effects highlight the importance of postulating entities or processes that intervene between input and output (Baron and Kenny, 1986). The central idea here is to understand whether the effects of KT were mediated by KCT to SP. In determining mediated effects, we used the bootstrapping processes in AMOS 18 (Zhao et al. 2010) which yielded a confidence interval for an indirect effect that did not contain the value zero between KT and PDS (.22). A mediated effect between KT and PDS was indicated. Furthermore, after running the full model (KT, KCT and PDS), the association of the path from KT to PDS was insignificant as indicated. Therefore, KT was fully mediated by KCT on PDS, suggesting no direct effect of KT on PDS, but an indirect 
effect running through KCT. The results indicated that KT did NOT enhance PDS. Instead it only did so indirectly and that it was KCT that had the direct impact on PDS.

(Insert Table 2 here)

(Insert Figure 4 here)

\section{Discussion}

Figure 5 captures our empirical findings and is used as the basis of our overall discussion.

(Insert Figure 5 here)

It shows that, companies engage in a learning process consisting of the transfer (KT) and the cross-transformation (KCT) of knowledge. The latter captures the activities of integrating diversified knowledge, of developing and then sharing this developed advanced knowledge with the other actors in the network. There is empirical support for better KT leading to better KCT. In the management learning literature, KT has been viewed as the centre of a firm's process between a parent firm and its allies (e.g. Argote, 2011; Miettinen et al., 2008). The idea of 'knowledge transformation' has also interested researchers, since new knowledge that “fits”, powerfully supplements what is already known and constitutes 'path construction’, as highlighted by Miettinen et al. (2008). A ‘path’ composed of successive interdependent processes is a hybrid phenomenon. In this sense, firm learning is central to interdependence as it is the driving force connecting the often diverse and heterogeneous network actors. Utilising Antonacopoulou and Chiva's (2007) expression, this is the power of learning to 'transform tensions into extensions'; in our case it reflects transforming 
existing knowledge into new knowledge. Building on this theory, our study provides a more detailed process depicting the phenomenon of 'co-evolution' in which companies bring back different types of knowledge, work on the collected knowledge, develop advanced knowledge, and more importantly, share this advanced knowledge with their network allies. This emphasises that KCT is an important, yet under-researched concept, in understanding management learning in a network setting,

Our second finding is that companies apply the skills of dialogue, articulation and experience for KT and then engage in articulation and pollination for KCT. The concepts of dialogue, articulation and experience have a mature root from the organisational learning literature (e.g. Nonaka, 1994; Huber, 1991; Larsson et al., 1998). Our study implies these skills are important, but nevertheless insufficient, to fully describe firm learning in network collaboration. Instead it is 'pollination' which is the important, yet under-researched, skill. The skill of pollination provides a better understanding of the theories such as 'added' effect (Miettinen et al., 2008), combinative capability (Kogut and Zander, 1992) and knowledge integration (Enberg et al, 2006).

A third key finding is that the association between $\mathrm{KT}$ and product development speed (PDS) is insignificant, whereas KCT is significantly associated with PDS. While the concept of KT has been at the heart of the learning literature (Walter et al., 2007), our study suggests that firms that draw upon KT alone may not fully benefit; instead it is KCT that helps to expedite NPD. We find that firms' learning in network collaboration leads to more advanced capabilities (Kogut, 2000; Miettinen et al., 2008). More importantly, we suggest that this higher level not only goes beyond organisational and projects boundaries, but also continues over time.

Finally, we find that KCT fully mediates the effect of KT on PDS, suggesting that KT does not directly impact on PDS; instead its impact runs through KCT. In the literature, 
knowledge acquisition from alliance partners is stressed. For example, Walter et al. (2007) emphasise that the degree of knowledge transfer is important in network collaboration. Nevertheless, they also notice a 'static' limitation of KT theory:

'...the framework (i.e. knowledge transfer) ignores the evolutionary process through which the external and internal networks of a firm arise and the subsequent impact of this formation of the capabilities of an organisation to acquire and diffuse information and knowledge...'

We also find that the effect of KT is static. However, when running through the process, KCT exerts dynamic effects. Put differently, the combination of the acts of knowledge acquisition and diffusion provides the manager with a better synergy for learning within business networks. Kogut (2000) describes this as shifting to a 'co-evolving' level.

\section{Conclusion}

\section{Implications for theory and practice}

This research responds to the call from Antonacopoulou and Chiva (2007) and from Enberg et al. (2006) for a more holistic understanding of learning across and beyond organisational boundaries. Several network alliance studies (e.g. Johnson et al., 2009) see knowledge transfer as a key driving force that pushes companies to collaborate with their network partners, but our evidence is that KT is not directly associated with product development speed. However, with KCT, firm learning through network alliances does improve product development speed. Our interpretation is that only those product developers who continue to work at a deeper, more synergized, level - knowledge cross-transformation - reap the full benefits of learning through network collaboration. 
Kogut (2000) reminds us that ‘network capabilities’ are a source of imputed value to the productivity of a firm. We suggest that, as the global economy has become more open and diverse, the need for new/novel knowledge has accelerated, meaning that KT alone is not sufficient. Instead, managers need to utilize the unique platform provided by network collaboration to stimulate and generate new ideas and novel knowledge. Hence, KCT reflects the value of network collaboration by enhancing product development speed. Companies not only create knowledge, but also store and use (or apply) this knowledge across the boundaries of various organisations and different timeframes. We recognise that networks are a valuable resource of firm (Singer and Helferich, 2008; Kogut 2000), but highlight that it is the crosseffect that shortens the lead time for new product development. Managers, seeking improved management leaning for competitiveness, are recommended to ensure KCT is taking place when working with network partners.

Second, we offer insights into important, yet under-researched, issues. We show how companies combine old know-how and create new knowledge. We found an important skill which we call 'pollination' because it fosters the formation of knowledge crosstransformation -a unique phenomenon in business network collaboration. These findings advance our understanding of concepts such as ‘collective invention’ (Allen, 1983), ‘combinative capability’ (Kogut and Zander, 1992), and ‘co-evolution’ (Miettinen et al., 2008; Walter et al., 2007). More importantly, they contribute to the study of management learning in network collaboration and provide directions for future research.

Third, we make the case for the wider use of sequential exploratory mix-methods research (Creswell, 2003). This approach has enabled us to conceptualise and test a learning process model that involves companies' engagement in dialogue, articulation, pollination and experience. Each aspect plays a crucial role in improving companies’ skills in working with network partners. It also augments our understanding of the learning skills (or converters) for 
product development speed, currently an unclear area in the existing literature. From the management learning perspective we have re-examined the existing knowledge-based view on identification, assimilation and application (Daft and Weick, 1984; Huber 1991; Rindfleish and Moorman, 2001; Day 2002) . We are re-assured that companies that engaged in 'dialogue' are more likely to recognize new knowledge, and engaged in ‘articulation' and ‘experience’ so as to assimilate knowledge. Enberg et al. (2006) have highlighted that attaining effective knowledge integration is an important challenge facing both general management and project managers. We found that companies apply 'pollination' to combine existing knowledge with new knowledge and then share newly gained knowledge with their network partners. These skills convert knowledge into superior positions and generate outcomes leading to more efficient product development.

Finally, this study broadens learning theory from a dyadic inter-organizational relationship to multi-faceted network relationships focused on managing product development. We echo the contention that in every new collaborative innovation that prior resource and competencies of a firm are complemented by the mastery of new entities and effects (Miettinen et la., 2008). We urge that a strategic reflection inherent in this evolving constellation is a necessary part of co-evolution. From a management learning perspective, it offers insights into the costs and benefits of openness in product innovation. One possible explanation for the high costs of openness is that companies merely engage in KT, but are unable to enjoy the fruits of external collaboration, because these require KCT. Through openness, companies engage with different partners to synchronise different types of knowledge and, most importantly, create new ideas.

\section{Limitations and future research}


We conclude by emphasising both the limitations of our current study and by suggesting how these might be addressed in future. First, we have examined successful product development projects as a whole, yet the literature suggests new product development is a staged process and, in some instances, success has yet to be achieved. Our provisional evidence points to learning being most valuable at the fuzzy, front-end of a project, but this remains untested. Second, our findings point to the returns from learning being higher with more complex projects, but this also requires more robust testing. Third, we only examined successful projects, partly because it is easier to identify successful cases where there is stronger management engagement with the resources. However, by no means all cases are successful and future research should also include unsuccessful projects within its research design. Fourth, despite being carefully selected for their unique expertise and their experience in successful product development projects, the study did rely on single informants and it is likely that reliability could be enhanced by using multiple respondents. Finally, as the global economy has become more open, management learning in business networks has become more complex. This study sheds some light on this topic from one important perspective the learning process - but related issues such as strategic learning (Miettinen et al., 2008; Walter et al., 2007) from networked relationship view; source credibility and trust from interrelationship view, are all issues waiting to be better explored. 


\section{Appendix 1(a): Descriptive Statistics}

\begin{tabular}{|c|c|c|c|c|}
\hline Construct / Items & Mean & S.D. & C.R. & AVE \\
\hline Dialogue & 5.69 & 1.09 & 0.89 & 0.81 \\
\hline ...listened to network partners. & 5.65 & 1.18 & & \\
\hline ...spoke to network partners. & 5.73 & 1.12 & & \\
\hline Articulation & 4.62 & 1.31 & 0.66 & 0.50 \\
\hline $\begin{array}{l}\text {...spent time in trial and error and developed a sense of feasibility of knowledge } \\
\text { from partners. }\end{array}$ & 4.84 & 1.52 & & \\
\hline $\begin{array}{l}\text {...it was a doable job to educate and train PD personnel with knowledge from } \\
\text { network partners. }\end{array}$ & 4.39 & 1.52 & & \\
\hline Pollination & 4.56 & 1.21 & 0.82 & 0.69 \\
\hline ...integrated knowledge from alliances in joint activity & 4.55 & 1.36 & & \\
\hline ...combined knowledge from alliances from previous projects. & 4.56 & 1.27 & & \\
\hline Experience & 4.88 & 1.26 & 0.87 & 0.77 \\
\hline ...had a high level of expertise with partner's technology/process/know-how. & 5.02 & 1.31 & & \\
\hline ...had a high level of experience with partners technology/process/know-how & 4.75 & 1.37 & & \\
\hline Knowledge Transfer & 4.83 & 1.11 & 0.85 & 0.74 \\
\hline ...had access to network partners knowledge & 4.86 & 1.10 & & \\
\hline ...collected network partners knowledge & 4.80 & 1.28 & & \\
\hline Knowledge Cross-Transformation & 4.56 & 1.13 & 0.77 & 0.54 \\
\hline $\begin{array}{l}\text {...brought back new knowledge from different important network partners in } \\
\text { joint activity. }\end{array}$ & 4.61 & 1.32 & & \\
\hline ...developed advanced knowledge through joint activity. & 4.62 & 1.32 & & \\
\hline ...shared newly gained knowledge to all network partners when it is needed. & 4.45 & 1.36 & & \\
\hline Speed-to-Market & 4.57 & 1.39 & 0.71 & 0.55 \\
\hline $\begin{array}{l}\text {... developed and launched faster than the major competitors for a similar } \\
\text { product. }\end{array}$ & 4.65 & 1.46 & & \\
\hline $\begin{array}{l}\text {...completed in less time than what was considered normal and customary for } \\
\text { our industry. }\end{array}$ & 4.48 & 1.52 & & \\
\hline
\end{tabular}

S.D.=Standard Deviation; C.R.=Composite Reliability;

$A V E=$ Average Variance Extracted

\section{Appendix 1(b): Construct Correlation}

\begin{tabular}{|c|c|c|c|c|c|c|c|c|}
\hline Construct & $\begin{array}{c}\text { Reliability } \\
(\alpha)\end{array}$ & 1 (Dia) & 2(Art) & 3(Pol) & 4(Exp) & $5(\mathrm{KT})$ & 6(KCF) & 7(PDS) \\
\hline 1. Dialogue & .88 & 1.00 & & & & & & \\
\hline 2. Articulation & .75 & $0.61 * * *$ & 1.00 & & & & & \\
\hline 3. $\quad$ Pollination & .82 & $0.45^{* * *}$ & $0.63 * * *$ & 1.00 & & & & \\
\hline 4. $\quad$ Experience & .93 & $0.21^{* *}$ & $0.20 * *$ & $0.40 * * *$ & 1.00 & & & \\
\hline $\begin{array}{ll}5 . & \begin{array}{l}\text { Knowledge } \\
\text { Transfer }\end{array} \\
\end{array}$ & .70 & $0.59 * * *$ & $0.62 * * *$ & $0.57 * * *$ & $0.38^{* * *}$ & 1.00 & & \\
\hline $\begin{array}{ll}\text { 6. } & \text { Knowledge } \\
\text { Cross- } \\
\text { Transformation }\end{array}$ & .71 & $0.48^{* * *}$ & $0.59 * * *$ & $0.64 * * *$ & $0.34 * * *$ & $0.59 * * *$ & 1.00 & \\
\hline $\begin{array}{ll}\text { 7. } & \begin{array}{l}\text { Product } \\
\text { Development } \\
\text { Speed }\end{array} \\
\end{array}$ & .88 & $0.19 * *$ & $0.43 * * *$ & $0.30 * *$ & $0.42 * * *$ & $0.25 * * *$ & $0.36^{* *}$ & 1.00 \\
\hline
\end{tabular}


Appendix 2: Sample Allocation

e-

Sample's Role $\quad \underline{\text { Business }}$ Tourism Energy $\underline{\text { Total }}$

\begin{tabular}{|l|c|c|c|c|}
\hline Hub Company & 1 & 1 & 1 & 3 \\
\hline Customer & 2 & 3 & 4 & 9 \\
\hline Customer's customer & 2 & 2 & & 4 \\
\hline Distributor & & 1 & & 1 \\
\hline Supplier & 2 & 1 & 2 & 5 \\
\hline Supplier's supplier & 1 & 1 & 1 & 3 \\
\hline Supplier's customer & 1 & 1 & 2 & 4 \\
\hline Competitor & 1 & & & 1 \\
\hline Joint venture & 1 & 1 & 1 & 3 \\
\hline 3rd party & 2 & 2 & 2 & 6 \\
\hline Total & 13 & 13 & 13 & 39 \\
\hline
\end{tabular}




\section{References}

Ahuja G (2000) Collaboration Networks, Structural holes, and Innovation: a longitudinal study. Administrative Science Quarterly 45: 425-455.

Akgün A, Byrne J, Keskin H, Lynn G and Imamoglu S (2005) Knowledge Networks in New Product Development Projects: a trans-active memory perspective. Information and Management 42 (8): 1105-1120.

Akgün A, Lynn G, Reilly R (2002) Multi-Dimensionality of Learning in New Product Development Teams. European Journal of Innovation Management 5 (2): 57-72.

Allen R (1983) Collective Invention. Journal of Economic Behaviour Organization 4(1): 124.

Antonacopoulou E (2006) The Relationship Between individual and Organisational Learning: new evidence from managerial learning practices. Management Learning 37 (4): 455 - 470. Antonacopoulou E and Chiva R (2007) The Social Complexity of Organizational Learning: the dynamic of learning and organizing. Management Learning 38 (3): 277 - 295. Appleyard M, Brown C and Sattler L (2006) An International Investigation of ProblemSolving Performance in the Semiconductor Industry. Journal of Product Innovation Management 23: 147-167.

Armstrong S and Overton T (1977) Estimating Non-Response Bias in Mail Surveys. Journal of Marketing Research 14: 396 - 402.

Argote L (2011) Organizational Learning Research: Past, Present and Future. Management Learning 42 (4): 439 - 446.

Argyris C and Schön D (1978) Organizational Learning: A theory of Action Perspective. Addison-Wesley Publishing Company, Inc.

Atuahene-Gima K and Wei Y (2011) The Vital Role of Problem-Solving Competence in New Product Success. Journal of Product Innovation Management 28: 81-98.

Baron R and Kenny D (1986) The Moderator-Mediator Variable Distinction in Social Psychological Research: conceptual, strategic, and statistical considerations. Journal of Personality and Social Psychology 51(6): 1173-1182.

Baumgartner H and Homburg C (1996) Applications of Structural Equation Modelling in Marketing and Consumer Research: a review. International Journal of Research in Marketing 13 (2): 139-161.

Beamish P and Berdrow I (2003) Learning from IJVs: the unintended outcome. Long Range Planning 36: 285-303. 
Bechky B (2003) Sharing Meaning across Occupational Communities: the transformation of understanding on a production floor Organization Science 14(3): 312-330.

Bresman H, Birkinshaw J and Nobel R (1999) Knowledge Transfer in International Acquisitions. Journal of International Business Studies 30(3): 439-462.

Brown J and Duguid P (2002) Local Knowledge: innovation in the networked age. Management Learning 33 (4): 427 - 437.

Clark K, Chew B and Fujimoto T (1987) Product Development in the World Auto Industry. 3: $729-771$.

Cohendet P and Llerena P (2007) the Emergence and Growth of an Improbable Laboratory in Economics and Management. European Management Review 4(1): 54 - 65.

Cooper R (1993) Winning at New Products: accelerating and process from idea to launch. Cambridge, MA: Addison-Wesley.

Creswell J (2003) Research design: quantitative, qualitative and mixed-methods approaches (2nd ed.). Thousand Oaks, CA: Sage.

Creswell J (2009) Research Design. SAGE Publications, Inc.

Cyert R and March J (1963) A Behavioural Theory of the Firm. Prentice Hall, Englewood Cliffs, NJ.

Daft R andWeick K (1984) Toward a Model of Organizations as Interpretation Systems. Academy of Management Review 9 (2): 284-295.

Day G (2002) Managing the market learning process. The Journal of Business and Industrial Marketing 17 (4): 240 - 252.

DiBella A , Nevis E, and Could J (1996) Understanding Organizational Learning Capability. Journal of Management Studies 33 (3): 361-379.

Duysters G and de Man A. (2003) Transitory Alliances: an instrument for surviving turbulent industries? RandD Management 33(1): 49-58.

Eisenhardt K (1989) Building Theories from Case Study Research. The Academy of Management Review 14(4): 532-550.

Enberg C, Lindkvist L and Tell F (2006) Exploring the Dynamics of Knowledge Integration: Acting and Interacting in Project Teams Management Learning 37 (2): 143-165.

Fornell C and Larcker D (1981) Evaluating Structural Equation Models with Unobservable Variables and Measurement Error. Marketing Research 18(3): 382-388.

Frankish J, Roberts R, Coad A, Spears T and Storey D (2013) Do Entrepreneurs Really Learn? Or Do They just Tell Us That They Do? Industrial and Corporate Change 22 (1): 73 106. 
Galbraith J (1973) Designing Complex Organizations. Addison-Wesley, Reading, MA

Gioia D, Corley K and Hamilton A (2012) Seeking Qualitative Rigor in Inductive Research: notes on the Gioia methodology. Organizational Research Methods 16 (1): 15-31.

Granovetter M (1985) Economic Action and Social Structure: the problem of embedded-ness. American Journal of Sociology 91 (3): 481-510.

Grant R (1996) Toward a Knowledge-based of the Firm. Strategic Management Journal 17 (Winter Special Issue): 109-122.

Griffin A and Page A (1996) PDMA Success Measurement Project: recommended measures for product development success and failure. Journal of Product Innovation Management 13: 478-496.

Gulati R (1999) Network Location and Learning: the influence of network resources and firm capabilities on alliance formation. Journal of Strategic Management 20(5): 397 - 420.

Håkansson H and Ford D (2002) How Should Companies Interact in Business Networks? Journal of Business Research 55(2): 133-139.

Håkansson H and Johanson J (2001) Business Network Learning. Elsevier Science Ltd, UK. Halme M (2001) Learning for Stainable Development in Tourism Networks. Business Strategy and the Environment 10 (2): 100 - 114.

Hamel G (1991) Competition for Competence and Inter-Partner Learning within International Strategic Alliances. Strategic management Journal 12: 83-103.

Hazen M (1994) A Radical Humanist Perspective of Inter-organisational Relationships. Human Relations 47(4): 393.

Hedlund G (1994) A Model of Knowledge Management and the N-form Corporation. Strategic Management Journal 15: 73 - 90.

Hemestsberger A and Reinhardt C (2006) Learning and Knowledge-Building in Open-Source Communities: a social-experiential approach. Management learning 37 (2): 187 -214.

Huber G (1991) Organisational Learning: the contributing processes and the literatures. Organization Science 2(1): 88-115.

Inkpen A.C. (1996), "Creating knowledge through collaboration", California Management Review, 1996, 39 (1), 123-140.

Inkpen A. (2000), “Learning through joint ventures: a framework of knowledge acquisition”, Journal of Management Studies, 37(7): 1019-1043.

Ingram P (2002) Inter-organizational Learning. The Blackwell Companion to Organizations, Blackwell Publishers Ltd: pp 642-663. 
Isaacs W (1993) Dialogue, Collective Thinking, and Organizational Learning. Organizational Dynamics 22(2): 24-51.

Johnson W, Piccolotto Z and Filippini R (2009) The Impacts of Time Performance and Market Knowledge Competence on New Product Success: an international study. IEE Transactions on engineering Management 56 (2): 219-228.

Kale P and Singh H (2007) Building Firm Capabilities through Learning: the role of the alliance learning process in alliance capability and firm-level alliance success. Strategic Management Journal 28 (10): 981 - 1000.

Kessler E, Bierly P and Gopalakrishnan S (2000) Internal vs. External Learning in New Product development: effects on speed, costs and competitive advantage. RandD Management 30 (3): 213-223.

Knoppen D, Sáenz M and Johnston D (2011) Innovations in a Relational Context: mechanisms to connect learning processes of absorptive capacity. Management Learning 42 (2): $419-428$.

Knudsen M and Mortensen T (2011) Some Immediate-But negative-Effects of Openness on Product Development Performance. Technovation 31: 54-64.

Kogut B (2000) The Network as Knowledge: generative rules and the emergence of structure. Strategic Management Journal 21 (3): 405 - 425.

Kogut U and Zander U (1992) Knowledge of the Firm, Combinative Capabilities, and the Replication of Technology. Organisation Science 3 (3): 383 - 397.

Lambert D and Harrington T (1990) Measuring Nonresponse Bias in Customer Service Mail Surveys. Journal of Business Logistics 11 (2): 5 - 25.

Larsson R, Bengtsson L, Henriksson K. and Sparks J (1998) The Interorganizational Learning Dilemma: collective knowledge development in strategic alliances. Organization Science 9(3): 285-305.

Liu R and Hart S (2011) Does Experience Matter? - A study of knowledge processes and uncertainty reduction in solution innovation. Industrial Marketing Management 40: 691-698. Lynch P and O'Toole T (2006) Involving External Users and Third Parties in the New Product Development Process Irish Marketing Review 18 (1/2): 29 - 37.

Mansfield T (1988) The Speed and cost of Industrial Innovation in Japan and the United states: external vs. internal technology. Innovation, Technology and the Economy: Selected Essays of Edwin Mansfield. Vol. 1 Elgar: Brook-field, VT.

Miles M and Huberman M(1994) Qualitative data Analysis, 2nd edition. Sage Publications Ltd. London, U.K. 
Miettinen R, Lehenkari J andTunnainen J (2008) Learning and Network Collaboration in Product Development: how things work for human use. Management Learning 39 (2): 203 219.

Moorman C (1995) Organisational Market Information Processes: cultural antecedents and new product outcomes. Journal of Marketing Research 32(3): 318-335.

Morgan D (2007) Paradigms Lost and Pragmatism regained: Methodological implications of combining qualitative and quantitative methods. Journal of Mixed Methods Research 1(1): 48-76.

Nonaka I (1994) A Dynamic Theory of Organizational Knowledge Creation Organization Science 5(1): 14-37.

Nonaka I and Takeuchi H (1995) The Knowledge Creating Company. Oxford University Press: New York.

Owen-Smith J, and Powell W(2004) Knowledge Networks as Channels and Conduits: the effects of spillovers in the Boston biotechnology community. Organisational Science 15(1): 5-21.

Oxford Dictionary and Thesaurus (2009), Third Edition, Oxford University Press, UK. Polanyi M(1966) The TacitDimension. Doubleday and Co. Garden City, NY.

Powell W, Koput K, Smith-Doerr L. (1996) Interorganizational Collaboration and the Locus of Innovation: networks of learning in biotechnology Administrative Science Quarterly 41: 116-145.

Powell W (1998) Learning from Collaboration: knowledge and networks in the biotechnology and Pharmaceutical industries. California Management Review 40(3): 228240.

Pyka A (2002) Innovation Networks in Economics: from the incentive-based to the knowledge-based approaches. European Journal of Innovation Management 5(3): 152-163. Rindfleisch A and Moorman C (2001) the Acquisition and Utilization of Information in New Product Alliances. Journal of Marketing 65 (2): 1-18.

Roan A and Rooney D (2006) Shadowing Experiences and the Extension of Communities of Practice: a case study of women education managers. Management Learning 37 (4): 433 454.

Rosenburg N And Steinmueller E (1988) Why are Americans such poor imitators? American Economic Review 78 (2): 229-234.

Schneider U (2007) Coping with the concept of knowledge. Management Learning 38 (5): $613-633$. 
Simonin B (1999) Ambiguity and the Process of Knowledge Transfer in Strategic Alliances. Strategic Management Journal 20(7): 595-623.

Singer J and Helferich J (2008), “Supporting R and D Support Groups. Research Technology Managemen 51 (1): 49-57.

Sinkula J (1994) Market Information Processing and Organizational Learning. Journal of Marketing 58 (1): 35-45.

Stuart T (1998) Network Positions and Propensities to Collaborate: an investigation of strategic alliance formation in a high-technology industry. Administrative Science Quarterly 43: $668-698$.

Teece D and Pisano G (1994) The Dynamic Capabilities of Firms: an introduction. Industrial and Corporate Change 3 (3): 537-356.

van de Vrande V, de Jong J, Vanhaverbeke W and de Rochemont M (2009) Open Innovation in SMEs: trends, motives and management challenges. Technovation, 29: 423-437.

Von Hippel, E (1990) Task Partitioning: an innovation variable. Research Policy 19: 407418.

Walter J, Lechner C and Kellermanns F (2007) Knowledge Transfer Between and Within Alliance Partners: private versus collective benefits of social capital. Journal of Business Research 60: $698-710$.

Yin R (2003) Case Study Research: design and methods. Third edition, SAGE.

Zhao X, Lynch Jr. J and Chen Q (2010) Reconsidering Baron and Kenny: myths and truths about mediation analysis. Journal of Consumer Research 37: 197-206.

Zollo, M and Winter S (2002) Deliberate learning and the evolution of dynamic capabilities. Organization Science 13 (3): 339-351. 
Table 1: A Summary of the Emergent Themes

\begin{tabular}{|c|c|c|c|}
\hline Emergent theme & Description & $\begin{array}{l}\text { The number of } \\
\text { interviewees whose } \\
\text { statements affirm the } \\
\text { theme } \\
\text { (Total number of } \\
\text { interviewees: } 39 \text { ) }\end{array}$ & Supported Literature \\
\hline $\begin{array}{l}\text { Knowledge transfer } \\
\text { (KT) }\end{array}$ & $\begin{array}{l}\text { The process of access, } \\
\text { assimilation and } \\
\text { dissemination of } \\
\text { knowledge }\end{array}$ & $\begin{array}{l}\text { e-Business: } 7 \\
\text { Tourism: } 10 \\
\text { Energy: } 8 \\
\text { Total: } 25 \text { (64\%) }\end{array}$ & $\begin{array}{l}\text { Cyert and March (1963); } \\
\text { Galbraith (1973); Daft } \\
\text { and Weick (1984); } \\
\text { Nonaka and Takeuchi } \\
\text { (1995); Inkpen (1996, } \\
\text { 2000); Walter et al. } \\
\text { (2007) }\end{array}$ \\
\hline $\begin{array}{l}\text { Knowledge cross- } \\
\text { transformation (KCT) }\end{array}$ & $\begin{array}{l}\text { The process of 'cross- } \\
\text { effect' and 'co-evolving', } \\
\text { where new/advanced } \\
\text { knowledge is created by } \\
\text { integrating diversified } \\
\text { knowledge }\end{array}$ & $\begin{array}{l}\text { e-Business: } 6 \\
\text { Tourism: } 9 \\
\text { Energy: } 7 \\
\text { Total: } 22 \text { (56\%) }\end{array}$ & $\begin{array}{l}\text { Under-researched } \\
\text { concept. Relevant } \\
\text { studies: Halme (2001); } \\
\text { Pyka (2002); Kogut } \\
\text { (2000); Walter et al. } \\
\text { (2007); Miettinen et al. } \\
\text { (2008); Liu and Hart } \\
\text { (2011) }\end{array}$ \\
\hline Dialogue (D) & $\begin{array}{l}\text { To speak with and listen } \\
\text { to one another in } \\
\text { mutuality, reciprocity } \\
\text { and co-inquiry: on-going } \\
\text { communication }\end{array}$ & $\begin{array}{l}\text { e-Business: } 13 \\
\text { Tourism: } 9 \\
\text { Energy: } 10 \\
\text { Total: } 32 \text { (82\%) }\end{array}$ & $\begin{array}{l}\text { Isaacs (1993); Hazen } \\
\text { (1994); Inkpen (1996); } \\
\text { Larsson et al. (1998); } \\
\text { Nonaka and Toyama } \\
\text { (2002) }\end{array}$ \\
\hline Articulation (A) & $\begin{array}{l}\text { To turn tacit knowledge } \\
\text { into explicit }\end{array}$ & $\begin{array}{l}\text { e-Business: } 9 \\
\text { Tourism: } 11 \\
\text { Energy: } 8 \\
\text { Total: } 28 \text { (72\%) }\end{array}$ & $\begin{array}{l}\text { Polanyi (1966); Hedlund } \\
\text { (1994); Nonaka (1994); } \\
\text { Grant (1996); Bresman et } \\
\text { al. (1999); Cohendet and } \\
\text { Llerena (2007); Kale and } \\
\text { Singh (2007) }\end{array}$ \\
\hline Pollination (P) & $\begin{array}{l}\text { To integrate knowledge; } \\
\text { knowledge fuse }\end{array}$ & $\begin{array}{l}\text { e-Business: } 9 \\
\text { Tourism: } 8 \\
\text { Energy: } 6 \\
\text { Total: } 23 \text { (59\%) }\end{array}$ & $\begin{array}{l}\text { Under-researched } \\
\text { concept. Relevant } \\
\text { studies: Pyka (2002); } \\
\text { Bechky (2003) }\end{array}$ \\
\hline Experience (E) & $\begin{array}{l}\text { To apply } \\
\text { knowledge/know how } \\
\text { from past learning }\end{array}$ & $\begin{array}{l}\text { e-Business: } 9 \\
\text { Tourism: } 12 \\
\text { Energy: } 6 \\
\text { Total: } 27 \text { (69\%) }\end{array}$ & $\begin{array}{l}\text { Powell (1998); Simonin } \\
\text { (1999); Pyka (2002); Liu } \\
\text { and Hart (2011) }\end{array}$ \\
\hline
\end{tabular}


Table 2: Structural Equation Modelling Results

\begin{tabular}{|l|c|c|c|c|}
\hline Hypothesis Tested & $\begin{array}{c}\text { Standardized } \\
\text { Estimate }(\beta)\end{array}$ & $\begin{array}{c}\text { Critical } \\
\text { Ratio }(t)\end{array}$ & $\begin{array}{c}P \\
\text { value }\end{array}$ & Supported \\
\hline $\begin{array}{l}\text { H1: Knowledge Transfer } \rightarrow \\
\text { Knowledge Cross-Transformation }\end{array}$ & 0.35 & 3.34 & $* * *$ & Yes \\
\hline $\begin{array}{l}\text { H2a: Dialogue } \rightarrow \\
\text { Knowledge Transfer }\end{array}$ & 0.27 & 2.88 & $* *$ & Yes \\
\hline $\begin{array}{l}\text { H2b: Articulation } \rightarrow \\
\text { Knowledge Transfer }\end{array}$ & 0.44 & 4.01 & $* * *$ & Yes \\
\hline $\begin{array}{l}\text { H2c: Experience } \rightarrow \\
\text { Knowledge Transfer }\end{array}$ & 0.23 & 3.38 & $* * *$ & Yes \\
\hline $\begin{array}{l}\text { H3a: Pollination } \rightarrow \\
\text { Knowledge Cross-Transformation }\end{array}$ & 0.25 & 2.36 & $* *$ & Yes \\
\hline $\begin{array}{l}\text { H3b: Articulation } \rightarrow \\
\text { Knowledge Cross-Transformation }\end{array}$ & 0.32 & 2.24 & $* *$ & Yes \\
\hline $\begin{array}{l}\text { H4a: Knowledge Transfer } \rightarrow \\
\text { Speed-to-Market }\end{array}$ & $\mathrm{ns}$ & $\mathrm{ns}$ & $\mathrm{ns}$ & Yes \\
\hline $\begin{array}{l}\text { H4b: Knowledge Cross Transf. } \rightarrow \\
\text { Speed-to-Market }\end{array}$ & 0.35 & 2.54 & $* *$ & Yes \\
\hline
\end{tabular}

Model Fit:

$\chi^{2}(76)=133.62, p=0.000, G F I=.92, C F I=.96, T L I=.94, R M S E A=.06$

$* * *$ Significant at $p<0.01$; ** significant at $p<0.05$; ns=not significant 
Figure 1: Data Structure - Network Learning Process
$1^{\text {st }}$ Order Concepts
$2^{\text {nd }}$ Order Themes
Aggregate
Dimensions

- Customers are fantastic 'leveller', listen to them (e-Business, supplier's supplier)

- In a three-way discussion, we talk to each other

(Tourism, supplier-1)

- Face-to-face talk is a direct and efficient way

(Energy, joint venture)

- We decide what we can pass them based on their existing experience (e-Business,customer-1)

- They are from hotel industry, they know how to grab the real issue (Tourism, supplier's supplier)

- This goes back to our earlier experience. I've been in this industry for 10 years (Energy, hub)

- It is important to make sure all the participated parties are aligned together to develop better solutions (e-Business, customer-2)

- They all raised their concerns and what they thought about (Tourism, customer-1)

- We involved all to make sure we all understand each other

- (Energy, supplier-1)

- A rich fusion approach makes our product unique, a combination of experts (e-Business, hub)

- We learnt a lot from all our partners, that helps us for a better solution (Tourism, hub)
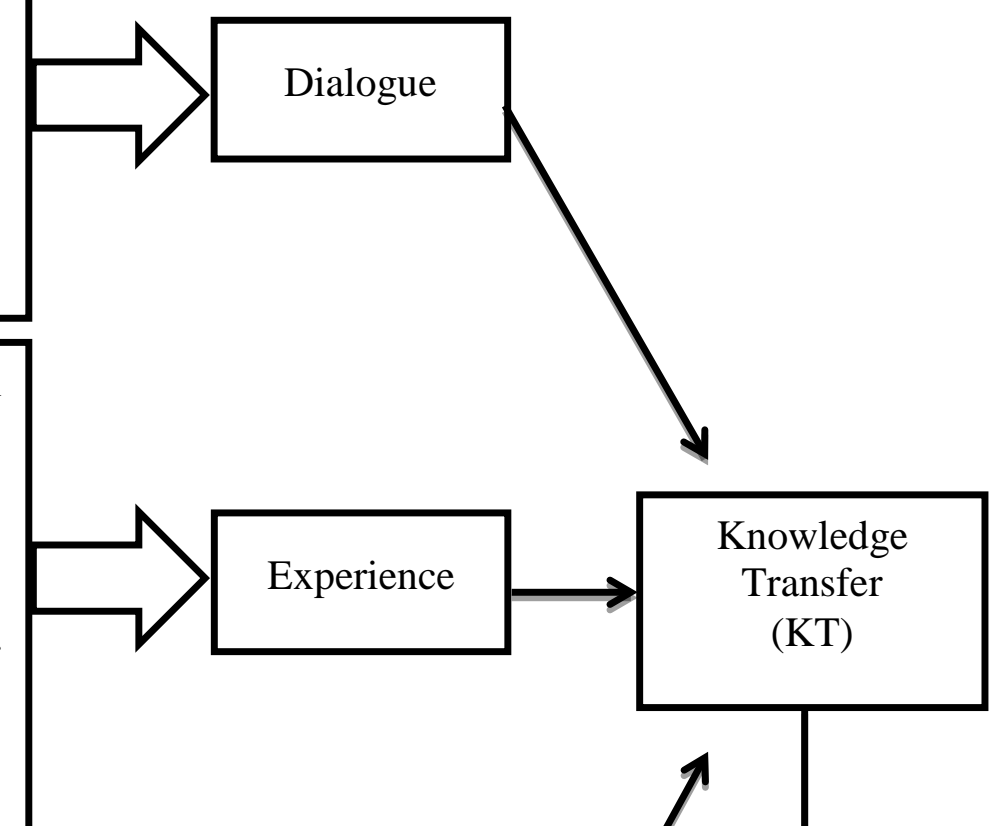

- We benefits from our previous projects.

(Energy, customer-2) 
Figure 2: the Engagement of Pollination

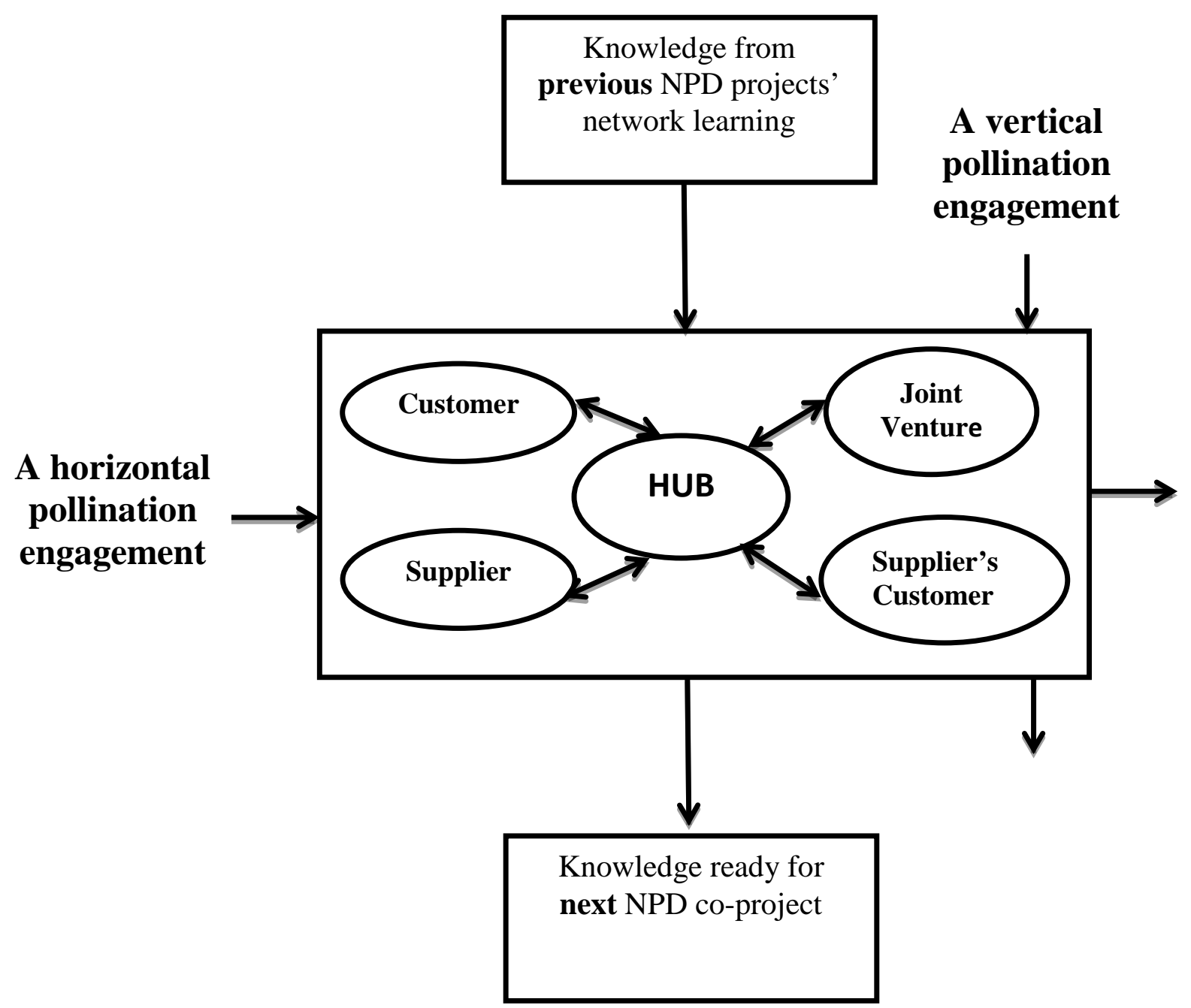


Figure 3: Conceptual Model - Network Learning Process and Its Effects

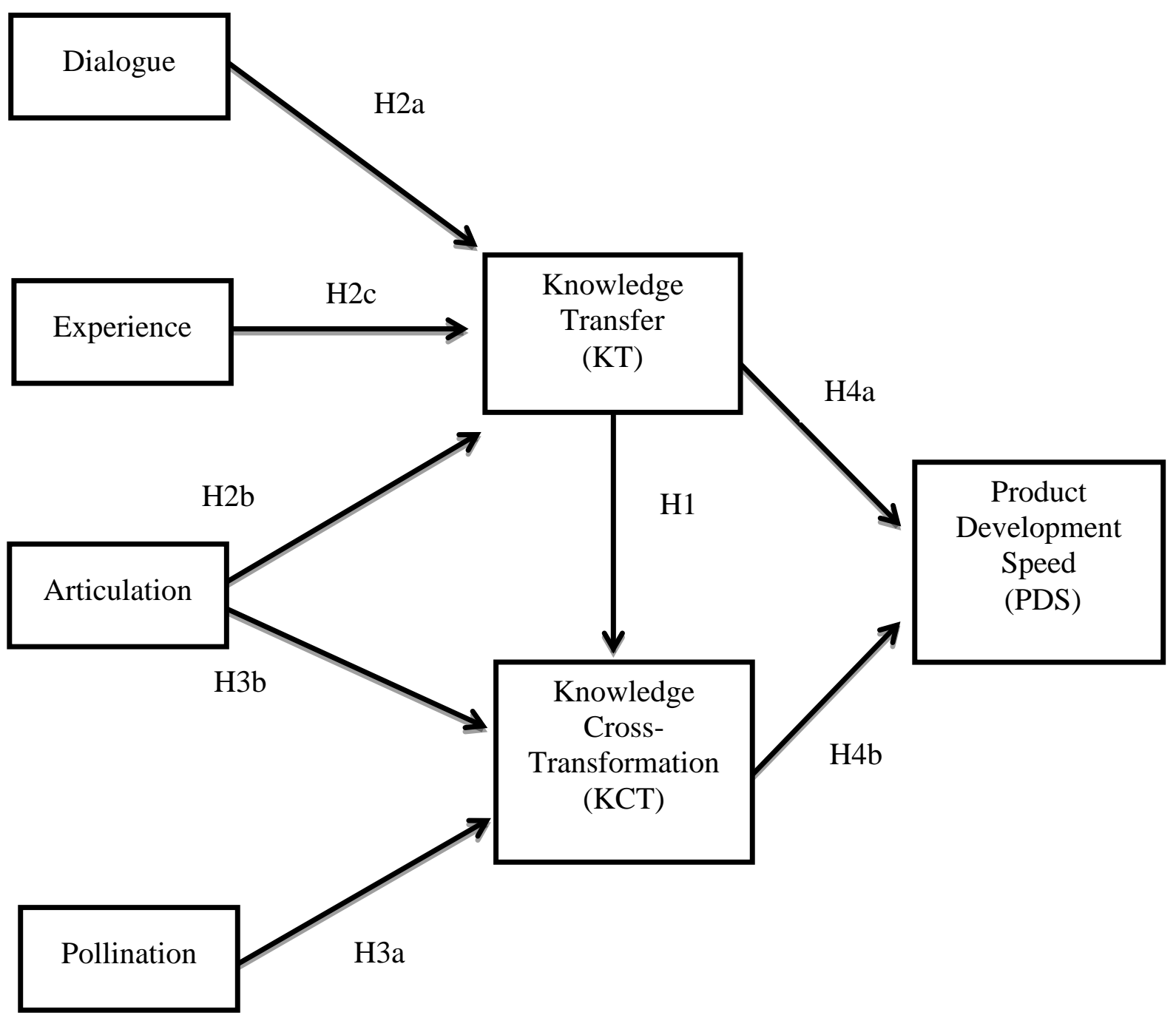


Figure 4: Structural Equation Modelling Results

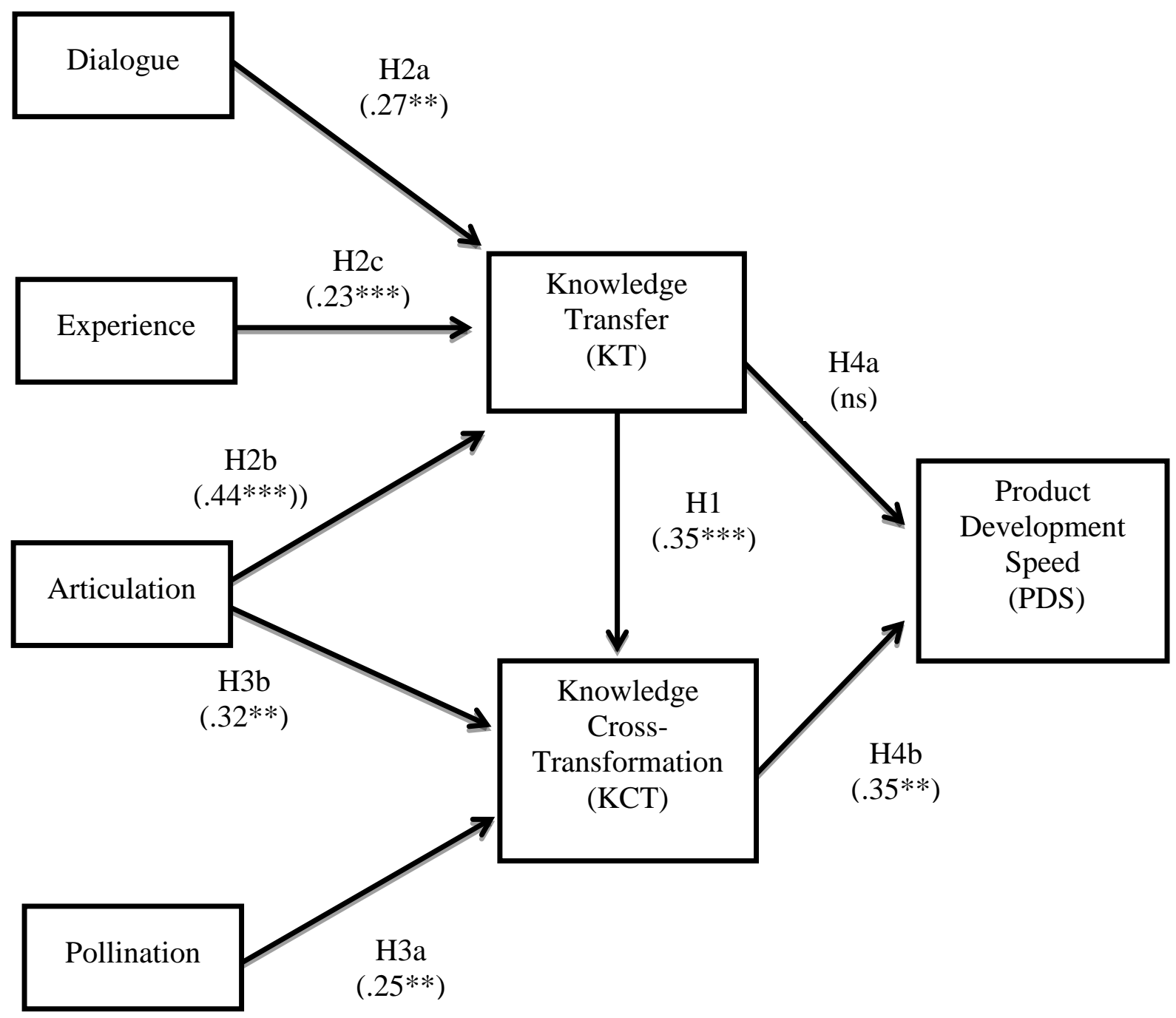

ns: not significant

*** $\mathrm{p}<0.01$

** $\mathrm{p}<0.05$ 
Figure 5: Empirically Derived Model

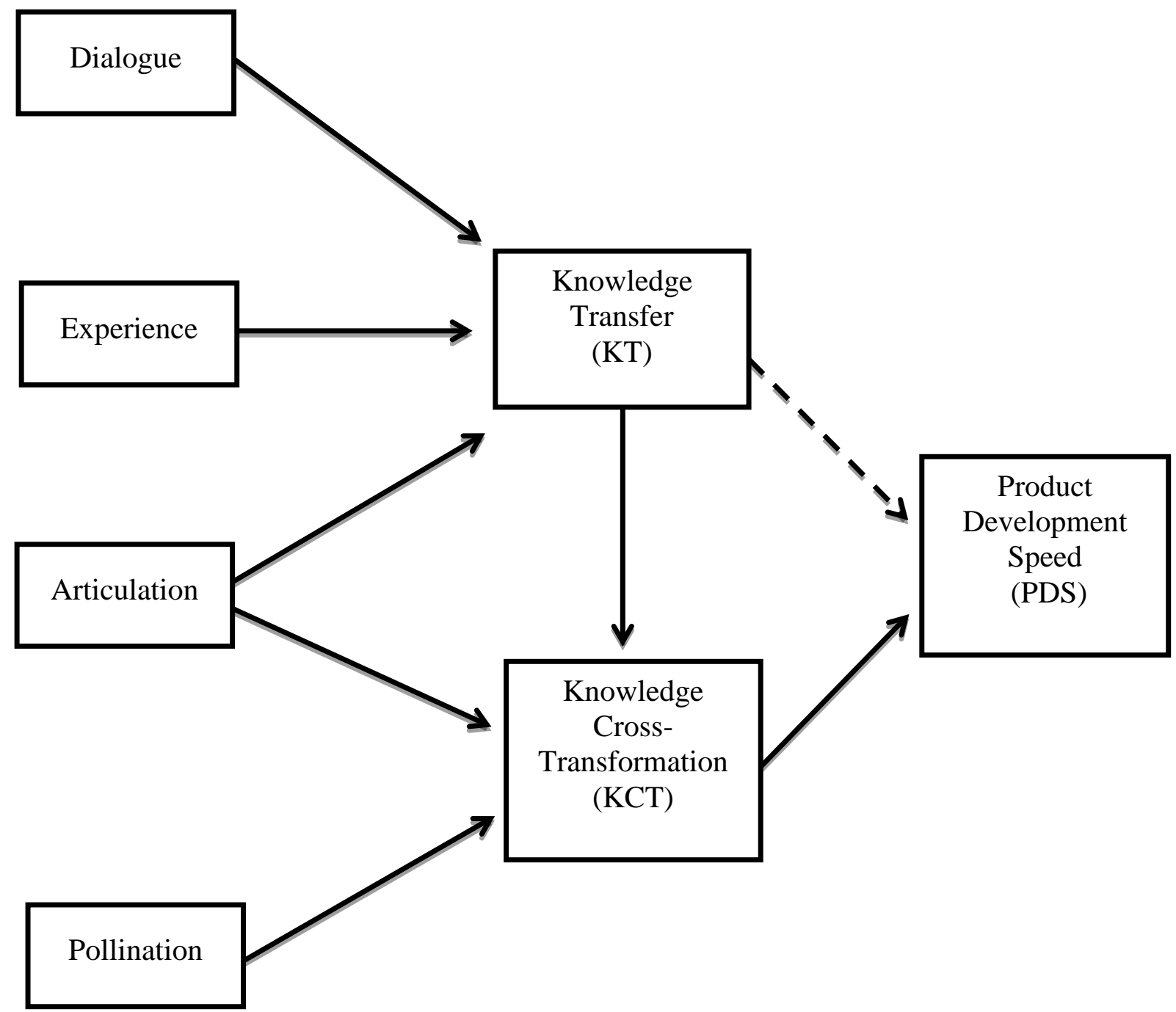

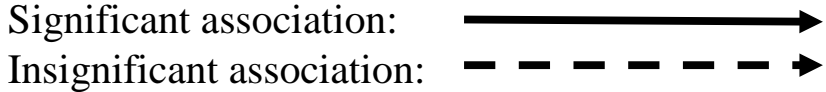

